\title{
"Marketing tools as the competitiveness enhancer of the Ukrainian film distribution market entities"
}

\begin{tabular}{|c|c|}
\hline \multirow{5}{*}{ AUTHORS } & Bozhena Sheremeta (D https://orcid.org/0000-0002-8596-409X \\
\hline & Nataliya Chukhray ED https://orcid.org/0000-0001-8591-2487 \\
\hline & R https://publons.com/researcher/2028192/nataliya-chukhray/ \\
\hline & Oleh Karyy (D https://orcid.org/0000-0002-1305-3043 \\
\hline & R http://www.researcherid.com/rid/D-1324-2016 \\
\hline ARTICLE INFO & $\begin{array}{l}\text { Bozhena Sheremeta, Nataliya Chukhray and Oleh Karyy (2019). Marketing tools } \\
\text { as the competitiveness enhancer of the Ukrainian film distribution market entities. } \\
\text { Innovative Marketing , 15(4), 88-101. doi:10.21511/im.15(4).2019.08 }\end{array}$ \\
\hline DOI & http://dx.doi.org/10.21511/im.15(4).2019.08 \\
\hline RELEASED ON & Wednesday, 18 December 2019 \\
\hline RECEIVED ON & Monday, 11 November 2019 \\
\hline \multirow[t]{2}{*}{ ACCEPTED ON } & Tuesday, 10 December 2019 \\
\hline & $((\mathrm{cc}) \mathrm{EY}$ \\
\hline LICENSE & $\begin{array}{l}\text { This work is licensed under a Creative Commons Attribution } 4.0 \text { International } \\
\text { License }\end{array}$ \\
\hline JOURNAL & "Innovative Marketing " \\
\hline ISSN PRINT & $1814-2427$ \\
\hline ISSN ONLINE & $1816-6326$ \\
\hline PUBLISHER & LLC "Consulting Publishing Company "Business Perspectives" \\
\hline FOUNDER & LLC "Consulting Publishing Company "Business Perspectives" \\
\hline
\end{tabular}

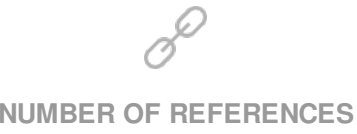

29
NUMBER OF FIGURES

4

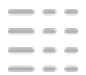

NUMBER OF TABLES

1

(C) The author(s) 2021. This publication is an open access article. 


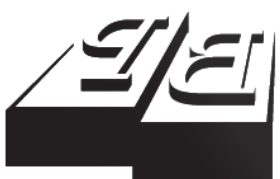

BUSINESS PERSPECTIVES

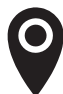

LLC "CPC "Business Perspectives" Hryhorii Skovoroda lane, 10, Sumy, 40022, Ukraine

www.businessperspectives.org

Received on: $11^{\text {th }}$ of November, 2019 Accepted on: $10^{\text {th }}$ of December, 2019

(c) Bozhena Sheremeta, Nataliya Chukhray, Oleh Karyy, 2019

Bozhena Sheremeta, Ph.D. student, Department of Management of Organizations, Lviv Polytechnic National University, Ukraine.

Nataliya Chukhray, D.Sc., Professor Vice Rector for Scientific Research, Lviv Polytechnic National University, Ukraine.

Oleh Karyy, D.Sc., Professor, Department of Management of Organizations, Lviv Polytechnic National University, Ukraine.

\section{(ㄷ) (i)}

This is an Open Access article, distributed under the terms of the Creative Commons Attribution 4.0 International license, which permits unrestricted re-use, distribution, and reproduction in any medium, provided the original work is properly cited.

\section{MARKETING TOOLS AS THE COMPETITIVENESS ENHANCER OF THE UKRAINIAN FILM DISTRIBUTION MARKET ENTITIES}

\begin{abstract}
The main goal of the article is to study the features of film marketing and distribution of film products in Ukraine and to determine what kind of marketing tools are appropriate to be used within a cinema network to ensure their competitiveness in the national film distribution market.

This article determines the characteristics of the movie market services and their compliance with modern consumer requirements, outlining the directions for increasing the usefulness of cinema-related services to consumers and developing a set of marketing tools to ensure the competitiveness of the cinema market.

The results of the assessment of the impact of competitive forces revealed that intra-industry competition has the strongest impact on private cinema networks, the consumers of film distribution services and potential competitors have the moderate influence, the suppliers and substitute services have a low level of influence.

According to the results of the survey, it can be concluded that cinemas are worth reducing the cost of tickets (this can be done by introducing the promotions and discounts for regular customers), since the solvency of a larger population does not correspond to the level of ticket prices. Also expanding the range of products will allow the consumers to spend more time in the cinema, which will lead to an increase in the value of the average check. Cinemas are quite realistic to open their own pizzerias or bars to add value to their customers.
\end{abstract}

\section{Keywords}

JEL Classification tool, film distribution market, entities, cinema chains, consumer value, marketing tools, film marketing

\section{INTRODUCTION}

Over the last ten years, the Ukrainian film distribution market has been growing rapidly, primarily by increasing the number of cinemas of the same format in cinema chains. The vigorous growth of the Ukrainian film distribution market is taking place following the business model of multi-screen cinema functioning in shopping and entertainment complexes, which is deemed currently to be the most commercially successful.

The film distribution market entities in Ukraine operate in the conditions of declining economic profitability due to several factors. One of these factors is a significant reduction in advertising in cinema chains, which provided an important source of profit. A significant increase in the cost of foreign distribution material and an increase in utility and rental payments while reducing advertising revenue and the cost of related services used by viewers has led to a decline in the profitability of cinemas. In such circumstances, the entities of the film distribution 
market need to review their marketing policies in order to increase the attendance by attracting new customers while actively seeking for the means to increase the sales of related services in cinemas, etc.

The abovementioned issues can be settled with the help of a properly chosen set of marketing tools that will contribute to the establishment of communication between the entities of film distribution market and consumers, providing the cinema networks with the opportunity to handle quickly the "signals" of the current environment and to thoroughly understand the needs of potential visitors and increase the added value of the services rendered, consequently, to ensure an increase in the flow of visitors that will, in turn, contribute to the growth of profitability of such institutions. Applying the methods of the group promotion called "below the line," which include promotions, merchandising, marketing of events, direct mailing, etc., it is possible to achieve an increase in the level of attendance at such places, and further, to solve the problem of reducing the economic profitability of enterprises operating in the film distribution market. Particular attention should be paid to the marketing of events, which will bring about the successful promotion of film and other related services through the creation and implementation of special events that may be associated with a particular film product, as well as being independent of it.

\section{LITERATURE REVIEW}

The research and systematization of the terminology of key positions within the process of development and formation of marketing as a science were led by the scientists of marketing, as well as public organizations of marketing insight. Among the main publications, it is advisable to highlight the work of Kotler, Burton, Deans, and Armstrong (2013) who, in their book "Marketing" (9th edition), underline that "Marketing, more than any other business function, deals with customers. Creating customer value and satisfaction is at the very heart of modern marketing thinking and practice. Marketing is about managing profitable customer relationships. The dual goal of marketing is to attract new customers by promising superior value and to keep and grow current customers by delivering satisfaction."

Bagozzi (1975), another influential scholar of the exchange paradigm, equates marketing with "exchange" by identifying three categories: restricted exchange (two-party reciprocal relationships), generalized exchange (reciprocal relationships among at least three parties), and complicated exchange (mutual relationships among at least three parties).

Baker (2014) in his work mentions that "Marketing strategy refers to an organization's integrated pattern of decisions that specify its crucial choices concerning products, markets, marketing activities, and marketing resources in the creation, communication, and/or delivery of products that offer value to customers in exchanges with the organization and thereby enable the organization to achieve specific objectives."

Marketing as a field of practice and academic discipline is a contentious area. This is partly due to the perception of marketing as finding ways in which to sell things to people that they do not want or need. Looking to Brown (2006), marketing has been blamed for many social ills such as obesity, consumerism, psychological ills, etc., and many have examined the dark side of marketing. In addition to this recognition of "the dark side" of marketing (Hirschman, 1991), there are various views on the historical development of the marketing function or marketing practice, tensions between those aligning themselves to the marketing management approach, critical marketing, post-modern marketing, relationship marketing, experiential marketing, green marketing, anti-marketing, and so on.

According to Smith (2006), the resistance towards marketing is increasing, and now much emphasis has been given to this phenomenon. Granata and Scozzese (2019) pay attention to an important factor that influences the changing way of marketing - the advent of digital technologies. This change was a direct consequence of the technological revolution this has led to a dramatic change in the way consumers treat products, companies, and markets. That is why the major cinema networks of Ukraine pay great attention to the development of their websites, applications, and send out the newsletters. 
Çimçek (2018), in his article, states that "It is seen that brands are following marketing communication strategies in social networks where they can effectively communicate with their customers. The most effective of these strategies is creating content. Methods to provide content shares about a brand should be used. For instance, organizing competitions, money refund, giving coupons, giving gifts, etc. Awaluddin and Hamid (2019), in their work "Interaction of social identity, empathy and planned behavior theories to understand domestic product purchasing intention," focused on finding the empathy in the relationship between the national identity and the intention to buy the domestic product. Marketers who care about value added feelings can create a content sharing environment that offers something that will enable customers to feel special."

Al-Zyoud (2018), in his work "Social media marketing, functional branding strategy and intentional branding," analyzed the relationship between the social media marketing strategy, strategic branding and functional branding to define the aspects of the social media marketing strategies in their greater inclination towards strategic branding than towards the functional one.

According to Ying Hon Ho (2016), social media have three basic uses in market research:

1. social media as method: several research firms now use social media as an important platform to interact with customers and consumers. For example, a researcher could link up with a chat room for sports car enthusiasts to run an online ethnographic inquiry within the target community;

2. social media as data: people now review social media content produced by users on both Twitter and Facebook, to name just a few;

3. social media as both method and data: There are now in existence market research online communities (MROCs), which are usually defined as "online focus groups on steroids."

These are closed and exclusive communities that normally engage well-focused target respondents enrolled for a participation of around 1-3 months.
Papakonstantinidis (2017), in his work "The SoLoMo customer journey: a review and research agenda," studied the interaction between the organization and the client to ensure a better understanding of effect of social networks, local marketing, and mobile apps on the consumer behavior. Derevianko (2018), in his work "Stakeholder engagement to replace traditional activities in Reputation Management System: insights from Ukrainian food processing companies," studied the involvement of the stakeholders in the reputation management processes in the digital economy, including the use of their activity in the Internet and the social networks.

Isahakyan and Shkarupa (2018) in their article "Innovation Marketing to Enhance Competitiveness: Case of Armenia and Ukraine" presented the hypothesis that there is a positive impact of innovative marketing on the country's competitiveness. Also they have identified the ways through which the use of innovative marketing tools can contribute both to increasing the competitiveness of the country as a whole and to solving individual problems: diversification of pricing strategies in foreign markets, formation and promotion of the country's brand, enhancing the country's competitiveness through social media, promotion of products of national companies world markets, etc.

Reshetnikova (2015) has noted that marketing as an enterprise subsystem, on the one hand, has the same external environment as the enterprise, on the other hand, has its external environment as an independent system

Teletov and Hryhorenko (2018) have identified several factors that have an individually or aggregate effect on consumer confidence in the enterprise. Among factors that have a positive effect on consumer confidence in the enterprises, the scientist highlights the following: "authority," "similarity," "credibility," "internship," "celebrity," "friendship," "communication frequency," "place," "placements," and "actual demo."

Many scholars are also interested in exploring the movie rental market. Ulin (2019) in his paper relates business theory and practice across key global market segments - film, television, and online/ 
digital - providing you with an insider's perspective that cannot be found anywhere else. An idea moves from concept to profit and how distribution dominates the bottom line: Hollywood stars may make headlines, but marketing and distribution are behind-the-scenes drivers converting the content into cash.

Kerrigan (2010) in her book "Film marketing" writes: "With significant improvements in home cinema technologies and the simultaneous increase in the cost of cinema attendance and decrease in the cost of such home cinema technologies, it is accurate to assume a shift to film consumption in the home, rather than at the cinema. This shift can be used to explain the relative decrease in cinema attendance, which has occurred across many developed film markets over the last decade. However, there are still significant returns at the cinema box office, which indicates that consumers are not fully abstaining from film consumption in cinemas", that is indicating the need for marketing in this area.

Sparrow (2007) had written: “A film company's advertising on Internet will be interactive and based on a model in which the customer comes to the company. The world wide web enables film companies to engage their consumers in the advertising itself. The most common form of internet advertising is world wide web. Banner advertisements are no longer just static files. They may include animation, direct response, and other interactivity."

Kim and Nora (2017) had studied the effects of distribution and exhibition integration on product mix and accessibility in the movie theater industry. Their model assumes that integrated cinemas distort the allocation of space in favor of their films, but also have greater incentives for demand information. Comparing actual demand for displacement with the actual distribution of seats in cinemas, they find that integrated theaters are more responsive than independent theaters, diverting significantly fewer consumers and achieving greater consumer welfare. The results of their study indicate that better demand forecasting in integrated theaters improves the allocation of seats enough to compensate for distortions due to foreclosures.
Bakalchuk (2019), among other things in his work, describes the proposals to optimize the management of the film distribution sphere in order to ensure its profitability, as well as the integrity of the national and cultural environment of Ukraine, suggesting the methods of integrating the Ukrainian cinema into the European market, having developed the recommendations to support the industry in the framework of global financial crisis.

Veres and Evoyan (2011) in their paper develop the main principles of the creation of an intellectual information system of film distribution activities.

The systematization of the literature and the approaches to addressing the problem of ensuring the competitiveness of entities of the Ukrainian film distribution market has shown that despite a large number of scientific works and significant achievements succeeded in the theory and practice of marketing, some issues have not yet been sufficiently investigated. It should be noted that only some aspects of the features of the film distribution market have been the subject of research covered by scientists.

Yet the scientific works of Ukrainian authors are do not pay enough attention to the features of functioning of the film distribution market in Ukraine, as well as to the formation and use of a set of marketing tools by cinema chains.

The goal of the article is to study the distribution of film products in Ukraine and to determine what kind of marketing tools are appropriate to be used within a cinema network to ensure their competitiveness in the national film distribution market. In order to achieve the above mentioned, the following objectives were set:

- to identify the features of functioning of the national film distribution market, as well as to study its competitive structure while applying Porter's Five Forces method;

- to determine the peculiarities of the services rendered within the film distribution market, as well as their ability to satisfy current demands of consumers; 
- to investigate areas of growth in the utility of film distribution services for consumers and the formation of a set of marketing tools, ensuring the competitiveness of film distribution market entities.

The outcome of the investigation may be useful for scientists who operate within the marketing field, as well as for managers of the Ukrainian film distribution market entities.

\section{METHODS}

Analysis of the competitive structure of the national film distribution market with the use of Porter's Five Forces Framework method (Porter, 2008) is used.

\section{RESULTS AND DISCUSSIONS}

As of the beginning of 2019, more than 170 cinemas and more than 20 distribution companies are operating in Ukraine. The Ukrainian film distribution market belongs to the service industry, in particular, the entertainment industry. The structure of film product development and distribution in Ukraine is shown in Figure 1.

The first step in film distribution is the production of film products. The so-called majors, i.e., major Hollywood studios such as Sony Pictures, Disney, Universal, Warner Brothers, and others, are active- ly working in the market, where there is a well-established scheme of film production and delivery of goods to the final consumer. The branches of these studios are presented in each large country, including Ukraine. For instance, Disney, 20th Century Fox, Warner Brothers. In addition to their movies, foreign majors work with independent products, acquiring the right to rent the latter.

Film markets are key events for sales agents as it is here that meetings take place with international distributors, films that do not secure distribution deals before completion are screened, and bidding wars may take place. For films in the early stages of development, where the creative team attached to the film is seen as strong, the sales agent sends the script to the main distributors with whom they have a relationship four to five weeks before the market, so that once they meet at the market, negotiations can begin (Kerrigan, 2005).

Such studio-majors prefer to cooperate with partner agents in the national film distribution market. According to Fellman (2006), distributors can enter into two different types of agreements with exhibitors regarding the share of profit. The first is the firm term agreement, where a film is licensed to an exhibitor for a fixed release term, and profit share is agreed between the exhibitor and the distributor. The distribution of film distribution market shares among distributors of film products in Ukraine is shown in Figure 2.

As reflected by Figure 2, the major distributor of films in Ukraine is "B\&H Film Distribution," cov-

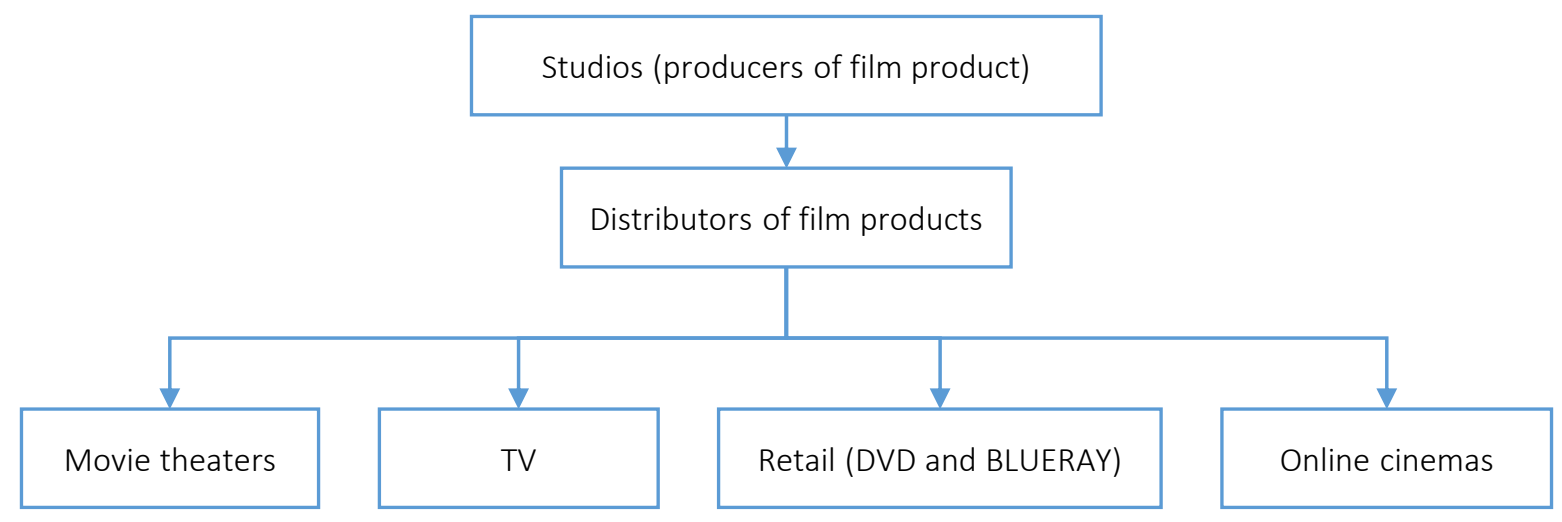

Figure 1. Structure of film production and distribution in Ukraine 


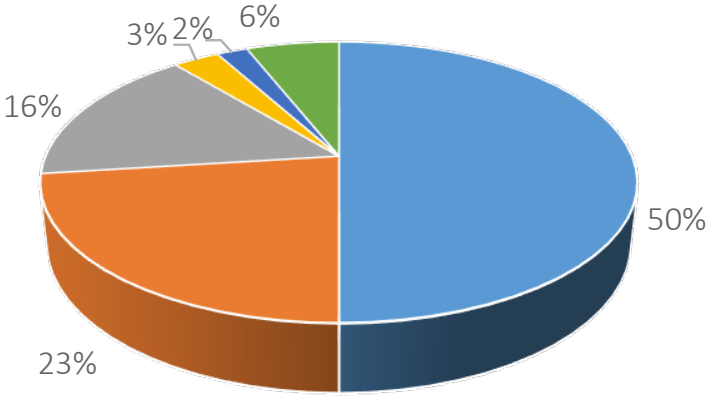

- B\&H Film Distribution

- Ukrainian Film Distribution

- Kinomania

- Volga

- Multi-media distribution

- Others

Figure 2. Distribution of film distribution market shares among film distributors in Ukraine, \%

ering $50 \%$ of the market while distributing films from Disney, Sony, Paramount studios and providing their products to cinema chains.

The next step of the film distribution is the release of the film product. When a major studio launches a film into production, it already knows the date of its premiere (a year or a year and a half later), although neither a single meter of the film has been shot yet nor a single gigabyte of the digital image has been taken. An advertising campaign comes in action, on which more than half of the film's budget is being spent. Representation offices in each country, where the film product will be shown, are also preparing for its release. At each film festival, the studios present the teasers, recaps, trailers, and film clips. All the cinemas that will launch these films have a clearly defined schedule for the following year. Since the entities of the film distribution market earn the bulk of their income in large-scale film products, their priority is the films produced by the majors. In this regard, independent companies face some problems that are difficult to solve in a short period. There are several key film markets - European (EFM), held during the Berlin Film Festival, Le Marché du Film, held during the Cannes Film Festival, and American film market, hosted in Los Angeles in November. That is where independent studios or sales-houses sell their released films, as well as those that are in the process of making. The scenarios of the films launched into production are to be sent to potential buyers all over the world. In fact, a distributor buys the names: the author is screened by books, time-proven director, famous actors, etc. The rights to distribution of a film most often are granted to the one who has offered more money.
Independent distributors release the film throughout their territory on their own (if there is a cinema center unit) or with the help of a large company or major. In the latter case, the company that assumes distribution obligations retains $10-17 \%$ of the box office.

Since the majors' representative offices enjoy significant capacities and opportunities, any independent distributor agrees with them on the film distribution, having a fair chance to make a profit on the film. An advertising campaign can cost several million dollars.

If a major studio launches a film, it is provided with an approved advertising campaign: poster film, banner, characters' posters; it is prohibited to change them. In the case of independent cinema, distributors often decide on their own how to present the acquired film to the viewer.

Figure 3 presents the distribution of shares of cinema chains operating in the Ukrainian film distribution market. Apparently, the two largest entities within the national film distribution market, namely Multiplex (30\%) and Planeta Kino (19\%), account for almost half of the market (49\%), while others have achieved market parity, covering from $3 \%$ to $8 \%$ of the national film distribution market.

As it commonly known within the environment of the enterprises' operation, the competitive power (components of Porter's Five Forces model) exerts the considerable influence on the latter, namely competition between sellers within the branch; firms offering substitute goods (substitutes); the possibility of the entry of new competitors within 


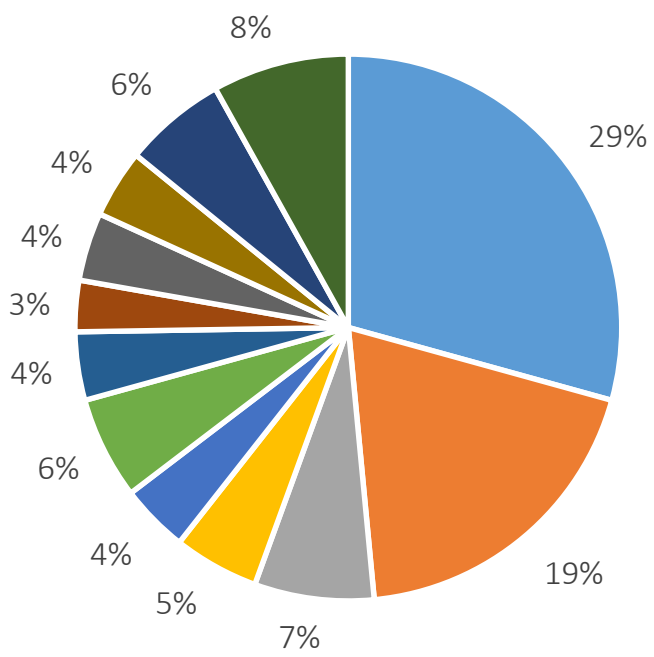

$\begin{array}{ll}\text { - Multiplex cinema } & \text { - Planeta Kino } \\ \text { - Cinema City } & \text { n Butterfly } \\ \text { - Oscar } & \text { - Kinopalats } \\ \text { - Linia Kino } & \text { - Kyivkinofilm } \\ \text { - KinoLand } & \text { - Odesa Kino } \\ \text { - Wizoria } & \text { - Kinotema }\end{array}$

Figure 3. Distribution of cinema chains segments operating in the Ukrainian film market, \%

the branch; the ability of suppliers of raw materials, materials and components used by the firm; the ability of the firm's products consumers to lay down the rules.

The Ukrainian film distribution market today has certain features in its development:

- the number of movie halls is increasing, but this is due to the opening of large multi-screen cinemas. Small cinemas (especially state and municipal ones) are being closed down. According to experts' forecasts, in 2019-2020, more than 70 new cinemas will be launched in Ukraine. Multiplex and Planeta Kino will be most actively developing their cinema chains;

- the state supports the film industry, including the production and launching of national films;

- in order to avoid individual screening through the improvement of cinemas and technology; for example, mass integration of Multiplex cinemas, 3D cinemas, IMAX cinemas, etc.;

- national cinemas are not adapted to the distribution of the author's films. There are more than a dozen cinemas all over Ukraine screening art house films. Concurrently, for instance, in Sweden, there is a tradition of distribution of such films spanning many years; they, according to various sources, account for 25-
$35 \%$ of the country's total box office;

- in Ukraine, the number of national companies providing services for the refitting of cinemas to digital technologies (Limited Liability Company "Kinoprokat-Ukraine," "Kinomir," Tine Line, etc.) is growing.

Cinema chains have been chosen as the object of this study, since these are the most important subjects of the film distribution market in Ukraine. It is efficient to start the research of the competitive environment of cinema chains by analyzing each of the market forces.

Table 1 provides the results of the analysis of the activity of national cinema chains using the Porter's Five Forces Framework method (Porter, 2008).

The results of the assessment of the impact of competitive forces revealed that the strongest impact on private cinema networks is caused by the intraindustry competition (10 points), while the average impact is triggered by the consumers of film distribution services (6 points in total) and potential competitors (9 points), while the low level of impact is provided by suppliers (4 points) and substitute services (2 points).

The film distribution market has an important feature and differs from the production industry since most of the services are provided by human 
Table 1. Competitive analysis of cinema chains by Porter's Five Forces Framework method

\begin{tabular}{|c|c|c|c|c|}
\hline \multirow{2}{*}{ Competitive factors } & \multirow{2}{*}{ Explanations } & \multicolumn{3}{|c|}{ Factor score } \\
\hline & & “3” & "2" & "1" \\
\hline \multicolumn{5}{|c|}{ 1. Intraindustry competition } \\
\hline $\begin{array}{l}\text { The number of entities in the } \\
\text { film distribution market }\end{array}$ & $\begin{array}{l}\text { The greater the number of enterprises } \\
\text { on the market, the higher the level } \\
\text { of competition and the risk of losing } \\
\text { market share }\end{array}$ & - & $\begin{array}{l}\text { Average level of market } \\
\text { saturation }\end{array}$ & - \\
\hline Market development rate & $\begin{array}{l}\text { The lower the rate of the enterprises' } \\
\text { development, the higher the risk of } \\
\text { constant market distribution }\end{array}$ & - & - & $\begin{array}{l}\text { Rapid pace of } \\
\text { development }\end{array}$ \\
\hline $\begin{array}{l}\text { Level of differentiation of } \\
\text { services in the market }\end{array}$ & $\begin{array}{l}\text { The lower the differentiation of } \\
\text { the service and the higher the } \\
\text { standardization services, the } \\
\text { greater the risk of uncertainty of } \\
\text { the consumer between different } \\
\text { companies operating in the market }\end{array}$ & - & $\begin{array}{l}\text { Marketed goods are } \\
\text { standardized in terms of } \\
\text { key properties, but with } \\
\text { extra benefits }\end{array}$ & - \\
\hline $\begin{array}{l}\text { Attractiveness of the film } \\
\text { distribution market }\end{array}$ & A clearly growing demand & $\begin{array}{l}\text { Clearly } \\
\text { manifested }\end{array}$ & - & - \\
\hline $\begin{array}{l}\text { Limitations on price } \\
\text { increases }\end{array}$ & $\begin{array}{l}\text { The fewer the opportunities for price } \\
\text { increases, the higher the risk of loss of } \\
\text { profit with a constant increase in costs }\end{array}$ & - & $\begin{array}{l}\text { There is an opportunity } \\
\text { to increase prices only to } \\
\text { cover cost increases }\end{array}$ & - \\
\hline Final score 10 & \multicolumn{4}{|c|}{$\begin{array}{l}\text { 1. } \geq 4 \text { points: low level of intraindustry competition } \\
\text { 2. 5-8 points: average level of intraindustry competition } \\
\text { 3. 9-12 points: high level of intraindustry competition }\end{array}$} \\
\hline \multicolumn{5}{|c|}{ 2. Consumer influence } \\
\hline Consumer influence & $\begin{array}{l}\text { There are a great many consumers of } \\
\text { film distribution services. They are of } \\
\text { different ages and with different levels } \\
\text { of solvency }\end{array}$ & - & $\begin{array}{c}\text { There is no significant } \\
\text { impact }\end{array}$ & - \\
\hline $\begin{array}{l}\text { The importance of the } \\
\text { product to the consumer }\end{array}$ & $\begin{array}{l}\text { These services are important for } \\
\text { consumers, as they provide an option } \\
\text { of organizing their leisure time }\end{array}$ & - & Clearly manifested & - \\
\hline $\begin{array}{l}\text { Propensity to switch to } \\
\text { substitute services }\end{array}$ & $\begin{array}{l}\text { The lower the uniqueness of the } \\
\text { company's service, the higher the } \\
\text { probability that the buyer will be able } \\
\text { to find an alternative without bearing } \\
\text { additional risks }\end{array}$ & - & - & $\begin{array}{l}\text { The company's } \\
\text { service is not } \\
\text { unique; there are } \\
\text { analoges (Internet } \\
\text { cinemas) }\end{array}$ \\
\hline Price sensitivity & $\begin{array}{c}\text { The higher the price sensitivity, the } \\
\text { more likely the customer will buy the } \\
\text { goods from competitors at a lower } \\
\text { price }\end{array}$ & - & - & $\begin{array}{l}\text { The consumer } \\
\text { will switch to } \\
\text { competitors } \\
\text { only if there } \\
\text { is a significant } \\
\text { difference in the } \\
\text { ticket price }\end{array}$ \\
\hline Final score 6 & $\begin{array}{r}1 . \geq 4 \\
\text { 2. } 5-8 \text { points: } \\
\text { 3. } 9-12\end{array}$ & $\begin{array}{l}\text { ints: low risk } \\
\text { erage level of } \\
\text { ints: high risk }\end{array}$ & $\begin{array}{l}\text { ustomer loss } \\
\text { eat of customer loss } \\
\text { customer loss }\end{array}$ & \\
\hline
\end{tabular}

\section{Impact of substitute services}

Prices $\quad \begin{gathered}\text { Lower prices and the availability of } \\ \text { substitute services create price line for } \\ \text { cinema networks }\end{gathered} \mid \begin{gathered}\text { Maintaining the required level of } \\ \text { service quality requires higher costs } \\ \text { than substituting services }\end{gathered}$


Table 1 (cont.). Competitive analysis of cinema chains by Porter's Five Forces Framework method

\begin{tabular}{|c|c|c|c|c|}
\hline \multirow{2}{*}{ Competitive factors } & \multirow{2}{*}{ Explanations } & \multicolumn{3}{|c|}{ Factor score } \\
\hline & & "3" & “2" & "1" \\
\hline \multicolumn{5}{|c|}{ 4. Supplier influence } \\
\hline The number of suppliers & $\begin{array}{c}\text { The smaller the number of suppliers, } \\
\text { the higher the probability of } \\
\text { unjustified price increases }\end{array}$ & - & - & $\begin{array}{l}\text { Sufficient option of } \\
\text { suppliers }\end{array}$ \\
\hline Limited supplier resources & $\begin{array}{c}\text { The higher the limited resources of } \\
\text { suppliers, the higher the probability of } \\
\text { price increases }\end{array}$ & - & - & $\begin{array}{l}\text { Limited supply of } \\
\text { technology }\end{array}$ \\
\hline $\begin{array}{l}\text { Prioritization of the direction } \\
\text { for the supplier }\end{array}$ & $\begin{array}{l}\text { The lower the priority of the industry } \\
\text { for the supplier, the less attention and } \\
\text { effort the supplier puts into it, the risk } \\
\text { of poor performance is being created }\end{array}$ & - & $\begin{array}{l}\text { High priority of the } \\
\text { industry for the supplier }\end{array}$ & - \\
\hline Final score 4 & \multicolumn{4}{|c|}{$\begin{array}{l}\text { 1. } \geq 4 \text { points: low supplier influence } \\
\text { 2. } 5-6 \text { points: average supplier influence } \\
\text { 3. } 7-8 \text { points: high supplier influence }\end{array}$} \\
\hline \multicolumn{5}{|c|}{ 5. Potential competitors impact } \\
\hline $\begin{array}{l}\text { Strong brands with high level } \\
\text { of loyalty }\end{array}$ & $\begin{array}{l}\text { The more confident the existing } \\
\text { brands in the industry are, the harder } \\
\text { it is for new players to join }\end{array}$ & - & $\begin{array}{l}2 \text { cinema chains cover } \\
\text { more than } 50 \% \text { of the } \\
\text { market }\end{array}$ & - \\
\hline Differentiation of services & $\begin{array}{l}\text { If enterprises have a more diverse } \\
\text { range of services and are featured due } \\
\text { to their uniqueness, the more difficult } \\
\text { it is for new enterprises to enter the } \\
\text { market }\end{array}$ & - & $\begin{array}{c}\text { There is no significant } \\
\text { differentiation }\end{array}$ & - \\
\hline $\begin{array}{l}\text { The readiness of existing } \\
\text { cinema networks to reduce } \\
\text { prices for services }\end{array}$ & $\begin{array}{c}\text { If entities can reduce prices to keep } \\
\text { their share of the market, it provides } \\
\text { for a significant barrier to entry of new } \\
\text { entities }\end{array}$ & - & $\begin{array}{l}\text { Cinema chains do not } \\
\text { resort to changes in } \\
\text { pricing policy }\end{array}$ & - \\
\hline Industry growth rate & $\begin{array}{l}\text { The higher the growth rate of the } \\
\text { industry, the more willing new entities } \\
\text { are to enter the market }\end{array}$ & High and growing & - & - \\
\hline Final score 9 & $\begin{array}{r}1 . \geq 5 \text { poi } \\
\text { 2. } 6-11 \text { point } \\
\text { 3. } 12-15 \text { po }\end{array}$ & $\begin{array}{l}\text { ints: low risk of new } \\
\text { ts: average risk of n } \\
\text { oints: high risk of ne }\end{array}$ & $\begin{array}{l}\text { entities entering } \\
\text { ew entities entering } \\
\text { w entities entering }\end{array}$ & \\
\hline
\end{tabular}

beings, while the industry makes greater use of machinery. The actions of some people lead to different results for others, which are different from the previous ones. There is a comparison between a service and a product, and unlike the latter, it has certain specific characteristics. For instance, Kotler (1999) highlights five characteristics: intangibility, inherence, volatility, impermanence, and lack of ownership. This list can be added with the service features that are most often found in other sources: heterogeneity; complementarity; simultaneity of production and consumption; usefulness, satisfaction of certain needs; short duration; impossibility of storage; inseparability from the service provider; urgency; heterogeneity in quality; quantitative valuation (price).

Services are less uniform and less standardized. This means that the results of purchasing a service may be uncertain. Uncertainty in the outcome of a service rendered creates a situation in which the customer is unable to manage and influence the result. According to Granata and Scozzese (2019), while purchasing the services, the buyer experiences a stronger risk rather than when buying a product.

One of the most important formulae of film marketing is the belief that the buyer does not request to the film product, but to the utility of the service consumption or solution of the problem, which can provide the service. According to Virvilaite, Piligrimiene, and Kliukaite (2015), social value has been defined as perceptual benefits acquired from a product's association with social class status, or a specific social group. Therefore, it can be concluded that the more benefits in terms of social benefits the customers have (e.g., belonging or admiration), the more likely they will engage in helping behavior. The consumer's choice is not aimed at the film production as such, but at the utility that he or she expects to get from watching it. This utility is determined by the fact that viewers watch the film in 
order to feel the overflow of emotions. Thus, it is in the interest of the film distribution market entities in Ukraine to characterize their target market through its key utility. The sought key utility offered by the film market - being overwhelmed with emotions - may be covered with the help of the same audiovisual playback, for example, by slot machines or computer games. Each benefit has a basic functional utility (consumer value) to which additional services can be added, generating secondary utility of different origins.

The features of film marketing allow identifying the marketing tools that are appropriate for cinemas to use in order to ensure the efficient performance of their activities.

The modern film distribution market provides its customers with a wide range of basic services, namely:

1) production, purchase, distribution, rollout, reproduction, dubbing, editing, demonstration and sale of cinematic and video products following the established procedure, both of its production and that of other owners, including feature films, chronicle-documentary films, advertising films, film and videotape processing, creation of commercial channels of cable and satellite television;

2) management and holding of pre-show events, premieres, presentations of films, film programs, information screenings of new films, meetings of viewers with famous cultural figures, days of culture, night offs, film festivals, meetings with viewers, and other cultural events;

3) transactions with studios, other companies or through film and video production;

4) advertising activities, including the production of advertising products, advertising campaigns, development of trademarks and corporate identity, advertising services in print and electronic publications, as well as in the media, including on their advertising media, Internet sites, etc.;

5) creation of elements of the film business and recreation infrastructure, including the man- agement and operation of entertainment centers and complexes;

6) output of products and services required for the activities of creative teams;

7) delivery of film copies, transportation under individual contracts, provision of movie tickets, statistical reporting forms and blank products;

8) rental and repair of household appliances and equipment, TV, audio, video and film equipment; sale, development, production, installation, adjustment, repair and maintenance of computer and telecommunications equipment, office equipment, general and special purpose equipment, including for the functioning and development of the cinema network;

9) management of catering, including cafes, bars, restaurants, children's and summer cafes in cinemas;

10) provision of services to the population and management of services on rewriting various media, digitizing videotapes, transcoding video formats, restoring and changing the structure of discs, video rendering, etc.

Additional services in the film market vary depending on the film distribution channel. At the stage of film distribution (film screening in the cinema), the audience is provided with a wide range of services independent of the film process: bars where you can buy popcorn and drinks, music in the cinema lobby, stereo sound system, comfortable seats in a movie hall, translation of a film, photo zone, etc. Thus, the owners of cinemas offer improved services, meeting the current needs of consumers.

Today, companies need to conduct the market research to maintain market positions and further development, as management decisions must be based on reliable and complete marketing information (Kosar, Mnyh, Krykavskiy, \& Leonova, 2018). For a better understanding of consumer needs, the authors have chosen a survey method. The most common research tool is the composite questionnaire shown in Figure 4. 


\section{QUESTIONNAIRE FOR MOVIE WATCHERS}

\begin{tabular}{|c|c|}
\hline $\begin{array}{l}\text { 1) Which movie viewing method do you prefer? } \\
\text { - In cinema } \\
\text { - } \quad \text { At home, via tv or the internet } \\
\text { - } \quad \text { In the open air cinema } \\
\text { - } \quad \text { Other }\end{array}$ & $\begin{array}{l}\text { 8) Check the box in one of the columns that matches your } \\
\text { answer (yes, hard to answer, no): } \\
\text { - I prefer to attend night sessions } \\
\text { I prefer to attend premiere } \\
\text { What matters to me is the availability } \\
\text { of bonus or accumulating cinema cards }\end{array}$ \\
\hline $\begin{array}{l}\text { 2) How often do you visit cinemas? } \\
\text { - } \quad 1 \text { time per week } \\
\text { - } \quad 1 \text { time per month } \\
\text { - } \quad 1 \text { time every half year } \\
\text { - } \quad \text { Other_-_-_--_-- }\end{array}$ & $\begin{array}{l}\text { 9) Which movie screening time is the best for you? } \\
\text { - } \quad \text { From } 10 \text { a.m. to } 1 \text { p.m. } \\
\text { - } \quad \text { From } 1 \text { p.m. to } 4 \text { p.m. } \\
\text { - } \quad \text { prom. to } 7 \text { p.m. } \\
\text { - } \quad \text { p.m. to } 11 \text { p.m. }\end{array}$ \\
\hline 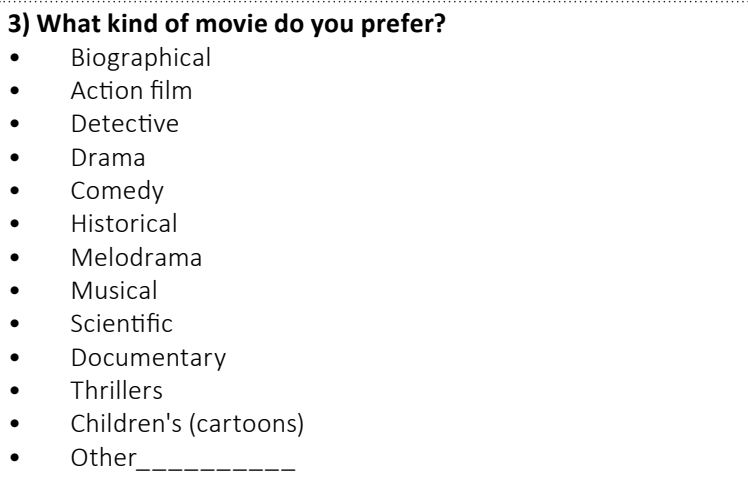 & $\begin{array}{l}\text { 10) What is the maximum ticket price you can buy? } \\
\quad 50-100 \cup A H \\
101-150 \cup A H \\
151-200 \cup A H \\
\text { - } 200 \text { and more }\end{array}$ \\
\hline $\begin{array}{l}\text { 4) Which cinema do you choose to visit? } \\
\text { - } \quad \text { Multiplex } \\
\text { - } \quad \text { Planeta Kino } \\
\text { - } \quad \text { Kinopalats } \\
\text { - } \quad \text { Other }\end{array}$ & $\begin{array}{l}\text { 11) How do you buy tickets for a session? } \\
\quad \quad \text { At the box office } \\
\text { - Using a movie theater site or mobile app }\end{array}$ \\
\hline $\begin{array}{l}\text { 5) Please evaluate the parameters that affect your choice of } \\
\text { movie theater (1 - not important, } \mathbf{1 0} \text { - very important): } \\
\text { - Convenient localization } \\
\text { - } \quad \text { Repertoire } \\
\text { - }\end{array}$ & $\begin{array}{l}\text { 12) What additional services would you like to see in cinemas? } \\
\text { - Arrangement of a play area for children aged 3-6 years with } \\
\text { a nanny } \\
\text { Creating a room to celebrate birthdays } \\
\text { Opening a "movie market" - places where you can buy a } \\
\text { variety of food, as well as paraphernalia from the films being } \\
\text { shown } \\
\text { Launch of the branded "online cinema" (as soon as the movie } \\
\text { leaves the cinema, it goes to its website, where it will be } \\
\text { possible to buy a monthly subscription) } \\
\text { Possibility to rent part of the premises for coworking } \\
\text { Other }\end{array}$ \\
\hline $\begin{array}{l}\text { 6) What would you like to add to the movie bar menu? } \\
\text { - } \quad \text { French hot dogs } \\
\text { - } \quad \text { Confectionery (muffins, cakes, panacotta, etc.) } \\
\text { - } \quad \text { Milkshakes } \\
\text { - } \quad \text { Ice cream } \\
\text { - } \quad \text { Pizza/burgers } \\
\text { - }\end{array}$ & $\begin{array}{l}\text { 13) Your age group: } \\
\text { - } 16-20 \\
\text { - } 21-25 \\
\text { - } 26-35 \\
\text { - } 36-45 \\
\text { - } 46-55 \\
\quad 56-66\end{array}$ \\
\hline $\begin{array}{l}\text { 7) What are the best days for you to go to a movie theater? } \\
\text { - Weekdays } \\
\text { - Weekend/holiday }\end{array}$ & $\begin{array}{l}\text { 14) Specify your gender: } \\
\quad \quad \text { Male } \\
\bullet \quad \text { Female }\end{array}$ \\
\hline
\end{tabular}

Figure 4. Questionnaire for movie watchers 
Method of data collection: the questionnaire was designed and hosted on Google Forms.

Data collection period: October 23, 2019 November 24, 2019.

Selective number of respondents: 160 people from Lviv, aged from 16 to 66 years.

According to the survey, the majority of movie viewers are people aged 16 to 35 years. The main way to watch movies for the respondents is to watch them at home through television and the Internet $(53.8 \%)$, while movie theaters prefer $43.1 \%$ of the respondents. The frequency of movie theaters in most respondents is once every half a year (44.4\%), but $34.4 \%$ visit cinemas once a month, which is a good indicator. Among cinema visitors, the most popular are the following types of cinema: comedy - 57.5\%; detectives, history, and melodrama - 28.1\%; thrillers $-24.4 \%$; fighters $-21,9 \%$. There are three major cinema networks in Lviv: Multiplex, Planeta Kino, and Kinopalats. The majority of respondents visit Multiplex (52.5\%), Planeta Kino (26.9\%), and Kinopalats (16.6\%). Also, the population aged 5566 often indicated their response that they did not visit any of the cinemas (3\%). The most important parameter when the respondents are choosing a movie theater is an affordable ticket price. Although, according to official data, the cost of tickets in Ukraine is one of the lowest in the world and reaches an average from 90 to $250 \mathrm{UAH}$.

In order to increase the number of movie theaters and to create added value for customers, the questionnaire included questions about additional services and menus in movie theaters. As for the movie bar menu, visitors would like to see the following items: pizza/burgers - 44\%; ice cream $25.6 \%$; milkshakes - 25\%; French hot dogs $-15 \%$. The respondents also submitted their offers: vegetarian food (0.6\%), more different flavors of popcorn (1.2\%), French fries (0.6\%), sushi (0.6\%).

Regarding additional services, the respondents most actively chose: Opening a "movie market" - places where you can buy a variety of food, as well as paraphernalia from the films being shown (49.4\%); launch of the branded "online cinema" (as soon as the movie leaves the cinema, it goes to its website, where it will be possible to buy a monthly subscription) $-46.9 \%$ and arrangement of a play area for children aged 3-6 years with a nanny (19.4\%).

In our opinion, the modern Ukrainian film distribution market entities should go beyond the framework of the supply of film products and services provided by their industry. We believe that in order to increase the consumer utility, it is required to expand the range of services rendered, in particular, babysitting services, availability of parking slots, souvenir shops (with an opportunity to buy popular film characters), holding of thematic weekend festivals, an option to take a "cinema bus" that would run from certain areas of the city to the cinema. At present, these additional services are not integrated into the traditional activities of national film distribution market entities. However, the free provision of additional services may increase the tangible benefits of visiting a cinema. Besides, it is worth noticing the survey data obtained by the Planeta Kino network, which demonstrates that the population perceives the cinema only as a place for movie watching, being ready to spend no more than three hours there.

\section{CONCLUSION}

The key figure in the film distribution market is the consumer (viewer); the success of any cinema distribution network depends on the consumer and the level of demand for its services. In a competitive market, the concept of "consume all goods" is no longer "working," and at the current stage of development, the producer (or seller) shall make every effort to promote his or her services and form the consumer demand.

The features of film marketing give grounds to determine the marketing tools that are appropriate for cinemas in order to ensure the efficient performance of their activities. The research has been carried 
out in the area of increasing the utility of film distribution services for consumers and confirms the need to develop a set of marketing tools to ensure the competitiveness of film distribution market entities.

To build up an effective marketing program that will influence the behavior of individual consumers, as well as generate demand for screening services, it is required to implement all elements of the marketing complex. Such a program should be aimed at achieving the goals of the film distribution market entities while providing the consumers with consumer utility.

Marketing tools of influence on consumer behavior and demand generation should be considered inseparable from the factors of influence on consumer behavior. The analysis of influence factors on consumer behavior gives insight into the features that determine the desire/willingness of the buyer (consumer) to purchase this or that product. Besides, marketing tools provide an opportunity to change the consumer behavior in the seller's desired direction. In the future, it is planned to survey the consumers of film distribution services and, particularly, the managers of the Ukrainian film distribution market entities. A comparative analysis of the results of the survey will help to identify the most common "pro" and "contra" of the cinemas (i.e., to identify their strengths and weaknesses), as well as will contribute to shaping an optimal business model needed for the development of cinema chains in Ukraine.

\section{REFERENCES}

1. Al-Zyoud, M. F. (2018). Social media marketing, functional branding strategy and intentional branding. Problems and

Perspectives in Management, 16(3), 102-116. https://doi.org/10.21511/ ppm.16(3).2018.09

2. Awaluddin, I., \& Hamid, W. (2019). Interaction of social identity, empathy and planned behavior theories to understand domestic product purchasing intention. Problems and Perspectives in Management, 17(1), 95-102. https://doi.org/10.21511/ ppm.17(1).2019.09

3. Bagozzi, R. (1975, October). Marketing as exchange. Journal of Marketing, 39(4), 32-39. https:// doi.org/10.2307/1250593

4. Bakalchuk, V. (2019). Vitchyzniana kinoindustriia yak faktor zabezpechennia tsilisnosti natsionalnoho ta kulturnoho prostoru [Domestic film industry as the factor of ensuring the integrity of the national and cultural space] (in Ukrainian). Retrieved from http://old.niss.gov.ua/Monitor/ mart2009/12.htm (accessed on September 10, 2019).

5. Baker, M. J. (2014). Marketing strategy and management (560 p.). Macmillan International Higher Education. Retrieved from https:// www.macmillanihe.com/page/ detail/marketing-strategy-andmanagement-m-baker/?sf1=barco de\&st $1=9781137025821$

6. Brown, S. (2006). The Marketing Code. Marshall Cavendish, Singapore. Retrieved from https:// www.researchgate.net/publication/316358221_The_Marketing_Code

7. Çimçek, Ü. (2018). Evaluation of Use of Social Media in Marketing Communication Activities of Institutions. European Scientific Journal, 48-62. Retrieved from http://eujournal.org/index.php/ esj/article/view/11196/10732

8. Derevianko, O. (2018). Stakeholder engagement to replace traditional activities in Reputation Management System: insights from Ukrainian food processing companies. Problems and Perspectives in Management, 16(4), 314-330. https://doi. org/10.21511/ppm.16(4).2018.26

9. Fellman, D. R. (2006). Theatrical distribution. In J. E. Squire (Ed.), The Movie Business Book (International 3rd ed.) (pp. 362374). McGraw-Hill, Maidenhead.

10. Granata, G., \& Scozzese, G. (2019). The Actions of e-Branding and Content Marketing to Improve
Consumer Relationships. European Scientific Journal January, 15(1), 58-72. https://doi. org/10.19044/esj.2019.v15n1p58

11. Hirschman, E. C. (1991). Secular morality and the dark side of consumer behavior: or how semiotics saved my life. Advances in Consumer Research, 18, 1-4. Retrieved from http://acrwebsite. org/volumes/7098/volumes/v18/ NA-18

12. Isahakyan, S., \& Shkarupa, O. (2018). Innovation Marketing to Enhance Competitiveness: Case of Armenia and Ukraine. Marketing and Management of Innovations, 3 , 162-173. http://doi.org/10.21272/ mmi.2018.3-14

13. Kerrigan, F. (2005). Evaluating the impact of an integrated supply chain on the process of marketing European feature films (Unpublished Ph.D. Thesis). University of Hertfordshire Business School. Retrieved from https://uhra.herts.ac.uk/handle/2299/14285

14. Kerrigan, F. (2010). Film Marketing. Elsevier Ltd. Retrieved from https://books.google.com. ua/books/about/Film_Marketing. html?id=ufMdvuuTQ7MC\&redir_ $\mathrm{esc}=\mathrm{y}$ 
15. Kim, I. K., \& Nora, V. (2017). Vertical Integration and Product Availability in the Movie Theater Industry. Retrieved from https:// research.nu.edu.kz/en/publications/vertical-integration-andproduct-availability-in-the-movietheate

16. Kosar, N. S., Mhyh, O. B., Krykavskiy, Ye. V., \& Leonova, S. V. (2018). Marketynhovi doslidzhennia [Marketing researches] (460 p.). Lviv: Vydavnytstvo Lvivskoi politekhniky (in Ukrainian).

17. Kotler, P. (1999). Marketing Management: Analysis, Planning, Implementation and Control (9th ed.). Prentice Hall College Inc. Retrieved from https://www. amazon.com/MARKETINGMANAGEMENT-AnalysisPlanning-Implementation/dp/ B001ADSOQ8

18. Kotler, P., Burton, S., Deans, K., \& Armstrong, L. (2013). Marketing (693 p.). Pearson Australia Group Pty Ltd.

19. Papakonstantinidis, S. (2017). The SoLoMo customer journey: a review and research agenda. Innovative Marketing, 13(4), 47-54. https://doi.org/10.21511/ im.13(4).2017.05)

20. Porter, M. (2008). Konkurentnoe preimushchestvo: kak dostich vysokogo rezultata i obespechit yego ustoychivost [Competitive advantage: how to achieve a high result and ensure its stability] (71 p.). Moscow: Alpina Pablisher (in Russian).

21. Porter, M. E. (2008). The Five Competitive Forces That Shape Strategy. Harvard Business Review, 86, 78-93. Retrieved from https:// www.hbs.edu/faculty/Pages/item. aspx? num $=34522$

22. Reshetnikova, I. (2015). The internal marketing in enterprise marketing system. Marketing and Management of Innovations, 1, 45-55. Retrieved from http:// mmi.fem.sumdu.edu.ua/en/journals/2015/1/45-55

23. Smith, J. W. (2006). Coming to Concurrence: Improving Marketing Productivity by Reengaging Resistant Consumers. In Does Marketing Need Reform? (pp. 15-25). New York, NY: M.E. Sharpe.

24. Sparrow, A. (2007). Film and Television Distribution and the Internet. London: Routledge. https://doi. org/10.4324/9781315582351

25. Teletov, A., \& Hryhorenko, V. (2018). Trust-creating factors for the clients and customers. Economic bulletin of National Technical University of Ukraine "Kyiv Polytechnical Institute", 15, 375-386. Retrieved from http:// irbis-nbuv.gov.ua/cgi-bin/opac/ search.exe?I21DBN=LINK\&P21D
$\mathrm{BN}=\mathrm{UJRN} \& Z 21 \mathrm{ID}=\& \mathrm{~S} 21 \mathrm{REF}=10$ $\& S 21 C N R=20 \& S 21 S T N=1 \& S 21 F$ $\mathrm{MT}=\mathrm{ASP} \_$meta\&C21COM=S\&2 S21P03=FILA $=\& 2$

S21STR=evntukpi_2018_15_41

26. Ulin, J. (2019). The Business of Media Distribution. New York: Routledge. https://doi. org/10.4324/9781351136624

27. Veres, O., \& Evoyan, E. (2011). Informatsiina intelektualna systema diialnosti kinoprokatu [Information intellectual system of cinema rental activity] (in Ukrainian). Retrieved from http://science.lpnu.ua/sites/default/files/journal-paper/2017/ jun/3349/0494.pdf (accessed on October 23, 2019).

28. Virvilaite, R., Piligrimiene, Z., \& Kliukaite, A. (2015). The relationships between consumer perceived value and loyalty. Transformations in Business and Economics, 14(1), 76-91. Retrieved from https://www.researchgate. net/publication/282187293_The _ relations_between_consumer perceived_value_and_loyalty

29. Ying Hon Ho, D. (2016, July). How market research has evolved over the past decade. Retrieved from https://www.marketstrategies. com/blog/2016/07/how-marketresearch-has-evolved-over-thepast-decade/ (accessed on March 27, 2017). 